\title{
СИНТЕЗ СЛОЖНЫХ ЭФИРОВ ГЛИЦЕРИНА И КАРБОНОВЫХ КИСЛОТ ДЛЯ КОСМЕТИЧЕСКОГО И ФАРМАЦЕВТИЧЕСКОГО ПРИМЕНЕНИЯ
}

\author{
Ю.Л. Зотов, Д.М. Заправдина
}

Волгоградский государственный технический университет, 400005, Россия, г. Волгоград, пр. им. Ленина, 28.

При производстве биодизеля путем переэтерификации масла метанолом (или другими спиртами) образуется глицерин в качестве побочного продукта, составляющего 10 мас\%. Таким образом, развитие технологий получения биодизельного топлива приводит к увеличению количества глицерина на мировом рынке.

Сложные эфиры глицерина и карбоновых кислот используются в качестве липофильной фракции в косметических составах, а также в качестве солюбилизатора активных ингредиентов в косметических или фармацевтических составах. Традиционно, синтез сложных эфиров глицерина и карбоновых кислот осуществляют этерификацией глицерина карбоновой кислотой с использованием сильных кислот в качестве катализаторов, таких как $\mathrm{H}_{2} \mathrm{SO}_{4}$, $\mathrm{H}_{3} \mathrm{PO}_{4}$ и др. Применение кислотных катализаторов приводит к образованию побочных продуктов, низкой селективности по образованию моноглицеридов и трудоемкой стадии нейтрализации реакционной массы для удаления катализатора.

Нами исследованы новые катализаторы на основе соединений кальция в процессе этерификации глицерина олеиновой кислотой. В качестве катализаторов были испытаны три группы соединений кальция: первая - оксид и гидроксид кальция, вторая - соль кальция органической кислоты и третья группа - алкоголяты кальция. Установлено, что алкоголяты кальция обладают высокой каталитической активностью, позволяют повысить конверсию сырья и селективность по образованию моноглицеридов по сравнению с оксидом, гидроксидом и карбоксилатом кальция. Таким образом, предложенный способ этерификации глицерина с использованием алкоголятов кальция в качестве катализатора, позволяет достигать высоких выходов моноглицерида, при этом существенно упрощается стадия удаления катализаторов, снижается количество отходов. Сущность разработанного способа заключается в каталитическом воздействии не на кислоту, а на спирт, что позволяет повысить его активность в процессе этерификации и избежать образования побочных продуктов, характерных при кислотном катализе процесса. 